\title{
DOCUMENTO
}

\section{BASES PARA A RENOVAÇÃO DO ENSINO DE LATIM}

Fernando de Azevedo

Apresentação de

Maria Angélica Cardoso 1

Silvia Helena Andrade de Brito $^{2}$

Considerando que o livro didático é uma criação da escola moderna burguesa, presente desde as propostas de Ratke e de Comênio nos séculos XVI e XVII, apresentamos aos leitores o documento Bases para a Renovação do Ensino de Latim. Nesse texto em que Fernando de Azevedo apresentou suas proposições sobre ou para o ensino de Latim, buscamos, principalmente, indícios de como ele pensava a utilização do livro didático em seu projeto pedagógico.

Fernando de Azevedo (1894-1974)teve sua formação ginasial como interno no Colégio Anchieta de Nova Friburgo, no Rio de Janeiro e mais tarde foi seminarista na Companhia de Jesus, iniciando o noviciado em Campanha, sul de Minas Gerais. No seminário aprofundou o estudo do Latim e foi ali que lecionou pela primeira vez, como professor substituto.

Em 1914, já em Belo Horizonte, foi nomeado professor substituto nas cadeiras de Psicologia e de Latim do Ginásio Mineiro.Ao mudar-se para São Paulo, em 1917, continuou a lecionar Latim, trabalhando inicialmente com aulas particulares;e também ministrando a mesma disciplina, "a convite de Mr. Sadler, no Ginásio Anglo-Brasileiro. Diante de minha carta em latim, não teve ele dúvida de me contratar para professor dessa língua no ginásio, sob sua alta direção" (AZEVEDO, 1971, p. 55). Ainda na condição de professor de Latim e Literatura ocupou, entre 1921 e 1926, o cargo de professor na Escola Normal de São Paulo.

Nesse trânsito pelo ensino de Latim $^{3}$ em São Paulo queAzevedo elaborou o documento Bases para a Renovação do Ensino de Latim (Arquivo do Estado de São Paulo, Ordem 6748), apresentado ao Secretário do Interior do Estado de São Paulo, em setembro de 1921.

Por esse documento, Azevedo critica o método até então utilizado. "Ensôsso e tardigrado, descoroçoante pela sua insipidez e desesperador pela sua esterilidade" são as palavras usadas para descrever o método que, conforme ele, prestavaum desserviço ao ensino. Outra crítica era referente à falta absoluta de um livro didático para a execução das aulas. A partir daí, Azevedo apresenta sua proposta.

A obra seria dividida em dois volumes, um para o ensino na Escola Complementar e outro para a Escola Normal, mas organizados de modo que um seja sequência lógica do outro, já que duas modalidades de ensino estavam voltadas à formação de professores. "O livro que proponho", diz ele, "adotará rigorosamente o método intuitivo e dispensará o uso da gramática e do dicionário".

O documento ora apresentado traz a organização dos livros que comporiam a obra, bem como as justificativas para sua adoção nos estabelecimentos de ensino Complementar 
e Normal. Azevedo encerra o texto afirmando que, com tal iniciativa, tinha "em mira fazer do Latim alegremente um ensino sério", despertando no aluno o gosto pela antiguidade e língua latina.

\section{Notas}

${ }^{1}$ Doutora em Filosofia e História da Educação pela UNICAMP, pesquisadora do Grupo HISTEDBRUNICAMP.

${ }^{2}$ Doutora em Filosofia e História da Educação pela UNICAMP, professora da UFMS-Campo Grande/MS e pesquisadora do GEPES/HISTEDBR-MS.

${ }^{3}$ Além desse documento, Fernando de Azevedo produziu as seguintes obras, relacionadas ao estudo da língua e cultura latinas: No tempo de Petrônio: ensaios sobre antiguidade clássica (1923); Jardins de Salústio: à margem da vida e dos livros (1924); O segredo da Renascença e outras conferências (1925); Páginas latinas: pequena história de literatura romana pelos textos (1927). 